Arkivoc

Free to Authors and Readers
A Platinum Open Access Journal for Organic Chemistry
Paper

Arkivoc 2021, part iii, 185-196

\title{
Triazole groups as biomimetic amide groups in peptides can trigger racemization
}

\author{
Toni Hättasch, ${ }^{a}$ Carsten Schmuck, ${ }^{\text {a§ }}$ Jochen Niemeyer ${ }^{a *}$ \\ a University of Duisburg-Essen, Faculty of Chemistry (Organic Chemistry) and Center for Nanointegration \\ Duisburg-Essen (CENIDE), Universitätsstrasse 2, 45141 Essen, Germany
}

Email: Jochen.niemeyer@uni-due.de

Dedicated to Prof. Lanny S. Liebeskind on the occasion of his $70^{\text {th }}$ birthday

Received 02-02-2021

Accepted Manuscript 03-08-2021

Published on line 03-11-2021

\section{Abstract}

Amino acids are key building blocks for the synthesis of chiral organic materials. In this context, $\alpha$-azido amino acids are interesting starting materials which allow the construction of functionalized, amino-acid based compounds by copper-catalyzed alkyne-azide click reactions. We have now employed this strategy for the synthesis of arginine-derivatives and found that the formation of the azide and the click reaction can be carried out in good yields and with almost no loss of stereopurity. However, further transformation by saponification/amide-formation led to significant racemization at the $\alpha$-carbon. This process was investigated in detail, showing that the triazole-moiety seems to be responsible for the facile racemization. Thus, the highly useful modification of $\alpha$-azido amino acids by the CuAAC-reaction needs to be used with caution when stereopure materials are desired.
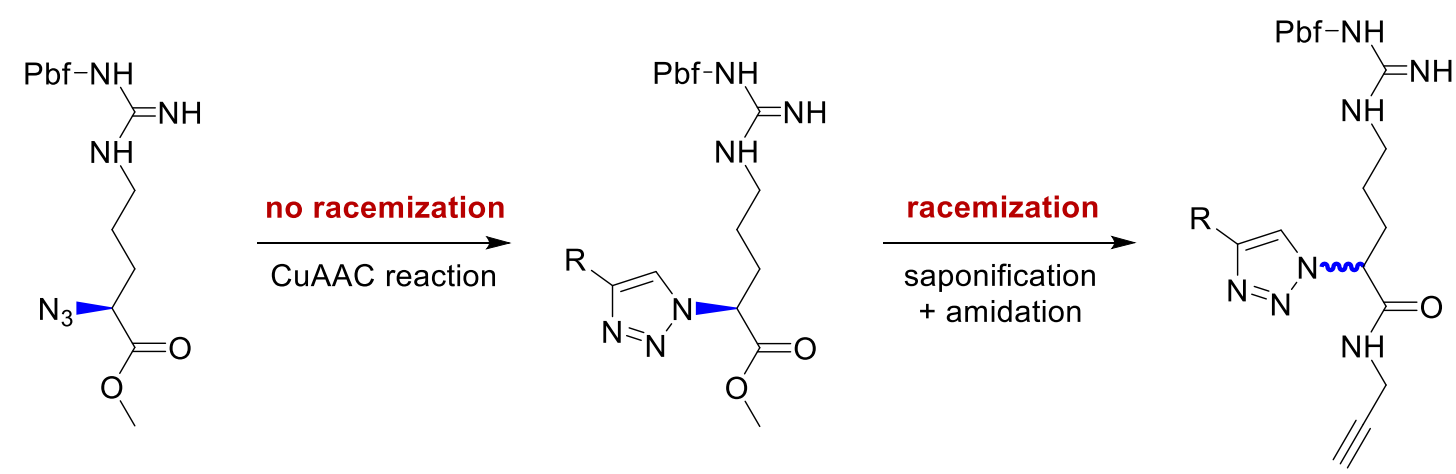

Keywords: Azido acids, arginine, click reaction, racemization, chiral HPLC 


\section{Introduction}

Amino acids are highly versatile building blocks in organic and bioorganic chemistry. They are routinely incorporated into larger molecular structures by functionalization via the $\mathrm{C}$-terminus, the $\mathrm{N}$-terminus or the side-chain, most prominently by amide coupling to other amino acids to generate the corresponding oligopeptides. ${ }^{1}$ Due to the importance of the chiral information that is present in natural $L$-amino acids, synthetic protocols have been developed that allow these transformations to take place without loss of chiral information at the chiral $\alpha$-carbon by racemization or epimerization, respectively. ${ }^{2}$

In the group of Carsten Schmuck, amino-acids, peptides or related compounds are routinely coupled to the cationic guanidiniocarbonyl-pyrrole (GCP) binding unit. ${ }^{3}$ The GCP-motif, which was developed by Carsten Schmuck, acts as a strong oxoanion-binder, so that especially its coupling to or combination with other cationic amino acids (such as lysine or arginine) has been important. The resulting GCP-lysine and GCParginine conjugates have been applied in anion-recoginition, ${ }^{4,5,6}$ materials chemistry ${ }^{7,8,9}$ and genetransfection..$^{10,11,12}$

To broaden the synthetic applicability of amino-acid derived building blocks, synthetic strategies other than the classical amide-coupling have been developed. In this context, $\alpha$-azido functionalized amino acids are of high interest, since they allow the straightforward and high-yielding coupling with alkyne-based coupling partners via the copper-catalyzed alkyne-azide click reaction (CuAAC). ${ }^{13}$ This methodology is especially interesting since the resulting triazole-linker can be seen as a bioisosteric replacement of the amide group (see Figure 1). ${ }^{14}$ Although it places the two substituents at a slightly larger distance than the amide group (5.0 vs. 3.9 $\AA$ ), the patterns of $\mathrm{H}$-bond-donor and -acceptor units are very similar. In the past, the formation of such triazole-based peptides has been reported both in racemic ${ }^{15}$ and in enantiopure form, ${ }^{16,17,18}$ and no racemization or epimerization was reported. For this reason, we became interested in using this approach for the coupling of the GCP-motif with $\alpha$-azido arginine, which would extend our methodology for the generation of amino acid-GCP conjugates. However, we found that epimerization at the $\alpha$-carbon is a serious limitation in this chemistry. While the synthesis of the $\alpha$-azido amino acid and the click reaction itself can be carried out without racemization, the subsequent transformation of the methyl ester into the propargylamide led to significant loss of stereopurity.
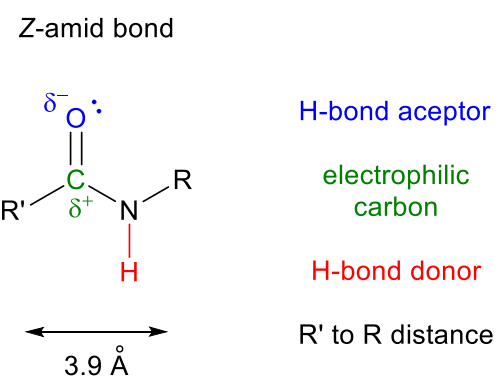

1,4-disubstituted triazol
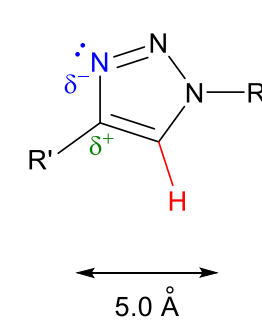

Figure 1. Comparison of the chemical properties of an amide group with the triazole group. ${ }^{14}$

\section{Results and Discussion}

Our investigations were triggered by our interest in the synthesis of GCP-arginine-conjugates. To this end, we designed compound (L)-5, which features a Boc-protected GCP-unit that is connected to the arginine- 
backbone by a triazole-linker stemming from the CuAAC reaction of the $\alpha$-azido arginine derivative with a GCP-based alkyne. Furthermore, (L)-5 contains a propargylamide at the $C$-terminus, which would allow its integration into larger, multidentate ligand frameworks by further click-reactions.

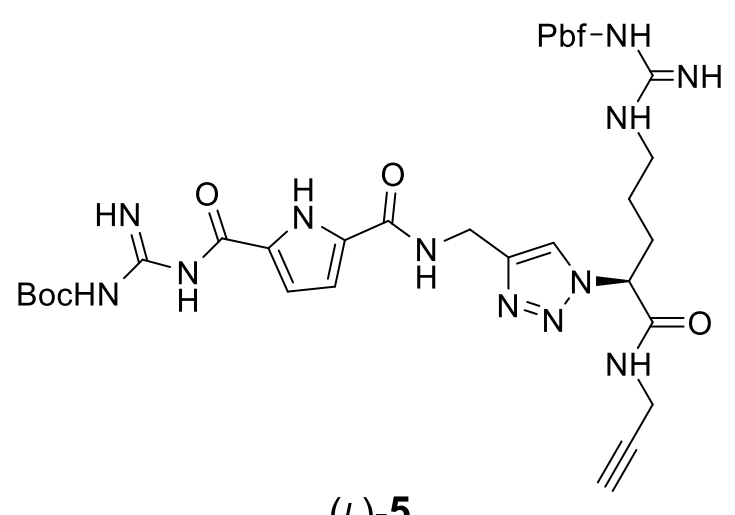

$(L)-5$

Figure 2. Design of compound (L)-5 as a GCP-containing, clickable arginine-derivative.

For the synthesis of $(L)-5$, we first transformed the commercially available Fmoc and Pbf protected arginine methyl ester [Fmoc-(L)-Arg(Pbf)-OMe, (L)-1] into the corresponding $\alpha$-azido derivative. This was carried out in a two-step, one-pot reaction: First, the Fmoc-protected precursor was deprotected with diethylamine and the resulting free amine was then directly transformed into the azide with imidazol-1sulfonyl azide hydrogensulfate. This azide-transfer reaction allows the introduction of the azide-group with retention of configuration at the $\alpha$-carbon. ${ }^{19}$ For other azide-transfer reagents see, for example, Steel ${ }^{20}$ or Pelletier. ${ }^{21}$ Indeed, this allowed the generation of the desired $\alpha$-azido derivative (L)-2 in $69 \%$ yield. Subsequently, we introduced the GCP-motif in a copper-catalyzed click-reaction with the Boc-protected GCPpropargylamide 3, yielding the GCP-arginine conjugate ( $L$ )-4 in $90 \%$ yield. Finally, the methyl ester was cleaved with $\mathrm{LiOH}$ and the carboxylic acid was transformed into the propargylamide $(L)-\mathbf{5}$ under standard coupling conditions with HCTU and NMM in DMF (68\% yield). In total, ( $L$ )-5 was obtained in a three-step sequence in $42 \%$ overall yield (see Scheme 1 ). 


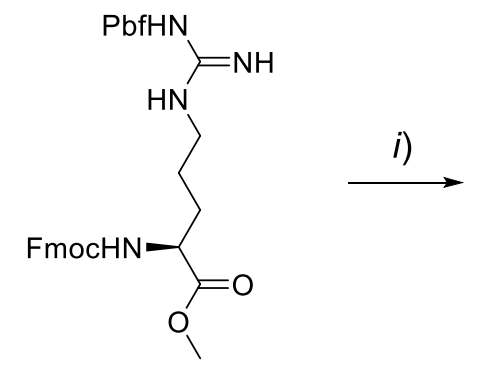

$(L)-1$

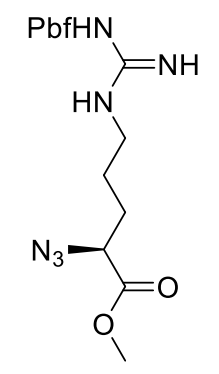

$(L)-2$

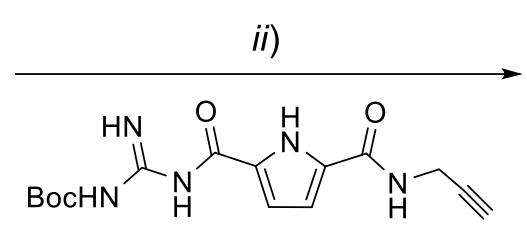

3

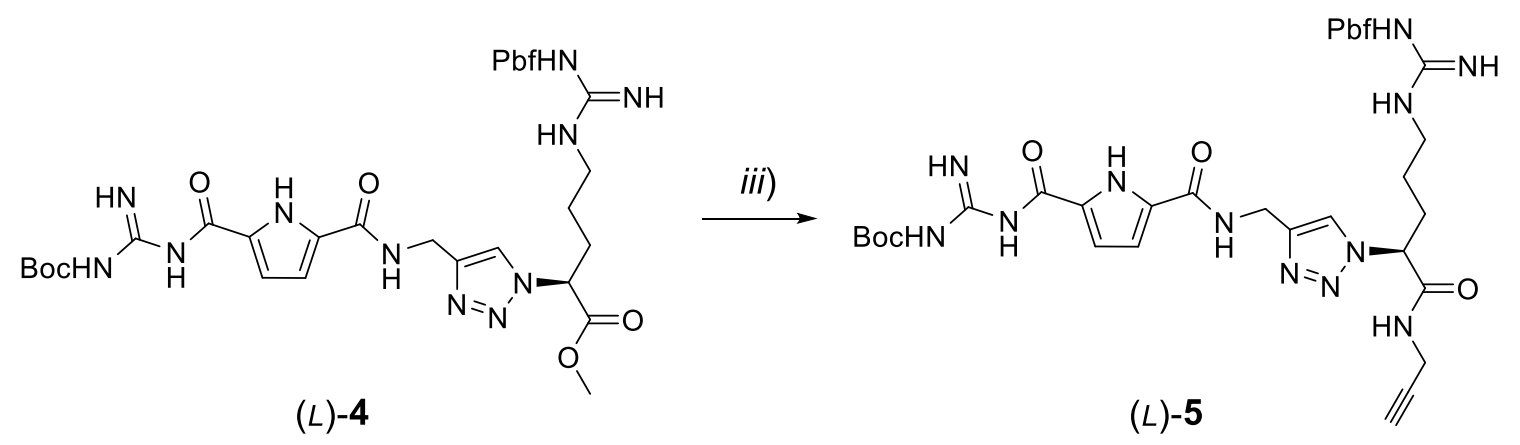

Scheme 1. Synthesis of target compound (L)-5. i) $\mathrm{Et}_{2} \mathrm{NH}, \mathrm{DMF}, \mathrm{RT}, 2 \mathrm{~h}$, then $\mathrm{K}_{2} \mathrm{CO}_{3}, \mathrm{CuSO}_{4} \cdot 5 \mathrm{H}_{2} \mathrm{O}$, imidazolium-1sulfonyl azide hydrogensulfate, $\mathrm{MeOH}, \mathrm{RT}, 12 \mathrm{~h}, 69 \%$; ii) 3, $\mathrm{CuSO}_{4} \cdot 5 \mathrm{H}_{2} \mathrm{O}, \mathrm{NaAsc}, \mathrm{THF} / \mathrm{H}_{2} \mathrm{O}, \mathrm{RT}, 12 \mathrm{~h}, 90 \%$; iii) $\mathrm{LiOH}, \mathrm{THF} / \mathrm{H}_{2} \mathrm{O}, 3 \mathrm{~h}, \mathrm{RT}$, then propargylamine, NMM, HCTU, DMF, RT, $12 \mathrm{~h}, 68 \%$.

Compound (L)-5 and the precursors ( $L$ )-2 and ( $L$ ) -4 could be isolated in chemically pure form and were characterized by standard analytical techniques (see the SI). In order to check the enantiopurity of all compounds, we also generated the corresponding racemic series [(rac)-5, (rac)-2 and (rac)-4, see the SI for details]. To our surprise, analysis by chiral HPLC (see Table 1 ) showed that ( $L$ )-5 only had an enantiopurity of $27 \%$ ee, so that an almost complete racemization had taken place. Unfortunately, analysis of the intermediate carboxylic acid was not possible on chiral NP-HPLC due to its high polarity. However, analysis of the precursor (L)-4 showed a significantly higher stereopurity $(92 \%$ ee), indicating that the racemization had largely taken place during the final transformation of the methyl ester into the amide.

Such racemization is of course undesired and would lead to the formation of diastereomers upon coupling of compound ( $L$ ) -5 with other chiral fragments (e.g. in the synthesis of multidentate ligands by linking three equivalents of ( $L$ ) -5 to a trisazide platform, which we initially planned for this compound). However, we believe that formation of such diastereoisomers may in many cases not be noticed by standard analytical techniques (e.g. ${ }^{1} \mathrm{H}$ NMR) due to the complex spectra of such larger frameworks and the small chemical shift differences between the resulting diastereomers. Accordingly, the racemization as a whole might remain unnoticed in similar synthetic protocols involving $\alpha$-azido amino-acids that are functionalized by click-reaction and further coupled to other fragments. For this reason, we investigated this unexpected racemization in more detail, with the intention of raising awareness of possible racemization processes in this chemistry.

First, we checked if the GCP-moiety in compound (L)-4 might play a role in the racemization process. For this reason, we performed the click-reaction of (L)-2 with 1-octyne (instead of the GCP-based alkyne 3 ). This gave to corresponding alkyl-substituted triazole ( $L$ )- 6 in $66 \%$ yield. Subsequent saponification of the methyl ester and HCTU-mediated amide-formation with propargylamine gave the target-compounds $(L)-7$ in $70 \%$ yield (see Scheme 2). 


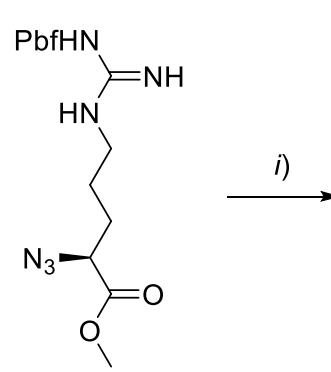

(L)-2

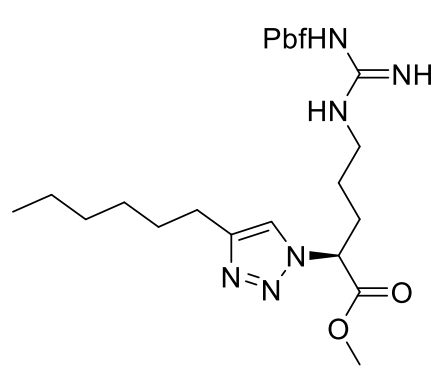

$(L)-6$

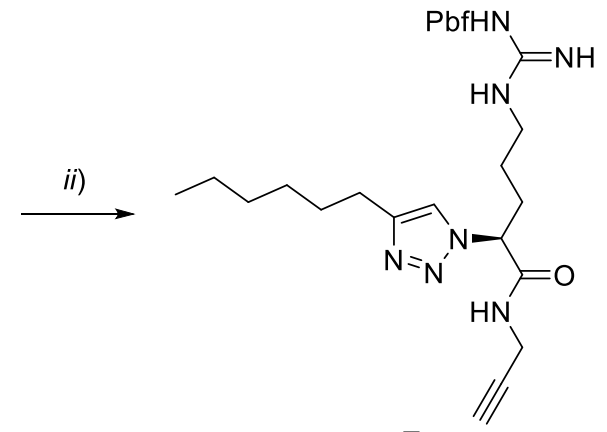

$(L)-7$

Scheme 2. Synthesis of hexyl-arginine derivative (L)-7. Reagents and conditions: i) 1-octyne, $\mathrm{CuSO}_{4} \cdot 5 \mathrm{H}_{2} \mathrm{O}$, $\mathrm{NaAsc}, \mathrm{THF} / \mathrm{H}_{2} \mathrm{O}, \mathrm{RT}, 12 \mathrm{~h}, 66 \%$; ii) LiOH, THF/ $\mathrm{H}_{2} \mathrm{O}, 3 \mathrm{~h}, \mathrm{RT}$, then propargylamine, NMM, HCTU, DMF, RT, $12 \mathrm{~h}$, $70 \%$.

Chiral HPLC-analysis of the methyl ester ( $L$ )- 6 and the propargyl amide $(L)-7$ showed a similar trend as found for the GCP-containing compounds (L)-4 and (L)-5. The CuAAC-reaction does not lead to significant racemization (92\% ee for (L)-6), while a major decrease in stereopurity is observed in the last step (45\% ee for (L)-7). This shows that the GCP-substituent does not play a major role, but indeed the transformation of the methyl ester into the propargyl amide seems to be the problem.

In order to elucidate this finding further, we then checked if the reaction conditions for the last step (saponification of the methyl ester by $\mathrm{LiOH}$, then HCTU-mediated amide-formation) also lead to a loss of stereopurity in the case of a standard amino acid or if the presence of the triazole-linker is the reason for the facile racemization. Thus, we used the Pbf- and Boc-protected arginine methyl ester ( $L$ )- $\mathbf{8}$ as a starting material and subjected this to the same reaction conditions to give the propargyl amide (L)-9 in $73 \%$ yield. In this case, chiral HPLC showed no racemization $(100 \%$ ee for (L)-9), thus indicating that the reaction conditions are applicable to standard amino acids without any racemization taking place.

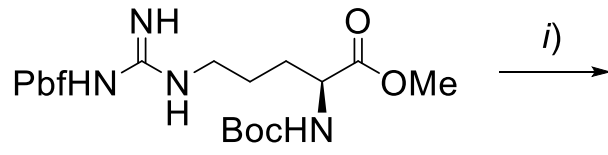

$(L)-8$

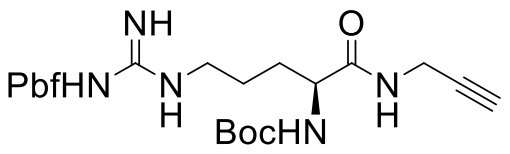

$(L)-9$

Scheme 3. Control experiment with the Boc-protected arginine methyl ester (L)-9. i) LiOH, THF/ $\mathrm{H}_{2} \mathrm{O}, 3 \mathrm{~h}, \mathrm{RT}$, then propargylamine, NMM, HCTU, DMF, RT, $12 \mathrm{~h}, 73 \%$.

As a consequence, it seems that the triazole-linker is the reason for the racemization that took place in the synthesis of compounds (L)-5 and (L)-7. We assume that the triazole leads to a higher acidity of the $\alpha$-hydrogen, as found for the related benzotriazoles. ${ }^{[22]}$ This is corroborated by the downfield-shift of this proton for ( $L$ )-5/7 in comparison the Boc-protected arginine derivate $(L)-\mathbf{9}(\delta=5.25 / 5.20 \mathrm{ppm}$ for $(L)-5 / 7$, c.f. $3.98 \mathrm{ppm}$ for (L)-9). Such higher acidity would favour $\alpha$-deprotonation under the basic conditions of saponification and amide-coupling, thus enabling the racemization in the case of the triazole-based compounds. Unfortunately, investigations to avoid this racemization by variation of the reaction conditions or by employing other coupling reactions, e.g. HBTU/HOBt, EDC/HOBt, HATU/HOAt and PyBOP were unsuccessful so far. Accordingly we have to conclude that application of $\alpha$-azido arginine indeed allows for the 
straightforward introduction of substituents (e.g. the highly functionalized GCP-moiety) by a simple clickreaction, but comes at the price of a increased tendency for racemization of the resulting triazole-derivative.

Table 1. Optical purities for compounds (L)-4/6/5/7/9 as determined by chiral HPLC ((L)-4: OD-H, $n-$ hexane:isopropanol $=75: 25$, isocratic, $0.5 \mathrm{~mL} / \mathrm{min}$; (L)-6: $\mathrm{AD}-\mathrm{H}, n$-hexane: isopropanol $=85: 15$, isocratic, $0.5 \mathrm{~mL} / \mathrm{min}$; (L)-5: IF-3, $n$-heptane:ethanol = 70:30, isocratic, $1.0 \mathrm{~mL} / \mathrm{min}$; (L)-7: OD-H, $n$-hexane:isopropanol = 75:25, isocratic $0.5 \mathrm{~mL} / \mathrm{min}$; (L)-9: AD-H, $n$-hexane:isopropanol = 75:25, isocratic, $0.3 \mathrm{~mL} / \mathrm{min}$ )

\begin{tabular}{|c|c|c|}
\hline Compound & Structure & $e e$ \\
\hline (L)-4 & & $92 \%$ \\
\hline$(L)-6$ & & $92 \%$ \\
\hline$(L)-5$ & & $27 \%$ \\
\hline (L)-7 & & $45 \%$ \\
\hline$(L)-9$ & & $100 \%$ \\
\hline
\end{tabular}




\section{Conclusions}

In conclusion, we have clarified that the synthesis of $\alpha$-azido derivate of arginine and its functionalization by copper-catalyzed alkyne-azide click reaction can be carried out in good yields and with little or no racemization at the $\alpha$-carbon. However, the subsequent transformation by saponification and HCTU-mediated amideformation leads to substantial racemization, independent of the exact substitution on the triazole fragment. Control experiments show that the reaction conditions for the saponification/amide formation do not lead to racemization for a standard $\alpha$-amino arginine derivative. This indicates that the triazole group is responsible for the facile racemization, most likely due to a decreased $\mathrm{p} K_{\mathrm{a}}$ of the $\alpha$-proton. As a consequence, a possible racemization/epimerization needs to be carefully controlled when employing $\alpha$-azido amino acids and their triazole-containing click products in preparing amino acid based materials.

\section{Experimental Section}

General. The NMR spectra were recorded with a BRUKER NEO 400 spectrometer $\left[{ }^{1} \mathrm{H}: 400 \mathrm{MHz},{ }^{13} \mathrm{C}: 101 \mathrm{MHz}\right.$. All measurements were performed at room temperature and using DMSO- $d_{6}$ as solvents. The chemical shifts are referenced relative to the residual proton signals of the solvents in the ${ }^{1} \mathrm{H}-\mathrm{NMR}$ (DMSO- $d_{6}: \delta=2.50 \mathrm{ppm}$ ) or relative to the solvent signal in the ${ }^{13} \mathrm{C}-\mathrm{NMR}$ (DMSO- $d_{6}: \delta=39.51 \mathrm{ppm}$ ). Assignments were made based on 2D-spectra (HSQC and HMBC). The apparent coupling constants are given in Hertz. In the description of the fine structure meanings are: $s=$ singlet, $b r s=$ broad singlet, $d=$ doublet, $t=$ triplet, $m=$ multiplet. High resolution ESI mass spectra were recorded on a THERMO SCIENTIFIC ORBITRAP LTQ-XL mass spectrometer or on a BRUKER DALTONICS MICROTOF ESI mass spectrometer. Normal phase analytical high performance liquid chromatography (HPLC) was performed with the following setup: ERMA DEGASSER ERC-3512, MERCK HITACHI INTELLIGent Pump L-6200A, ChIRALCEL AD-H column, OD-H column $(0.46 \times 25 \mathrm{~cm})$, KNAUER SMARTLINe UV-Detector 2600 (detection wavelength $220 \mathrm{~nm}$ ).

Materials. For thin layer chromatography (TLC) analysis throughout this work, PolygramR SIL G/UV254 TLC plates (silica gel $0.2 \mathrm{~mm}, 40 \times 80 \mathrm{~mm}$ ) were used. Visualization of the spots was carried under a $254 \mathrm{~nm}$ UV light source and, if necessary, stained by permanganate or ninhydrin or and heated with heat gun. The products were purified by flash column chromatography on silica gel 60M (40-63 $\mu \mathrm{m})$ which was purchased from MACHERY-NAGEL. Tetrahydrofuran was freshly distilled from sodium-benzophenone. Dimethylformamide was distilled under vacuum and stored under argon over a drying agent. Ethyl acetate was distilled under vacuum and stored under argon with potassium carbonate as a drying agent. Aqueous work up and column chromatography were carried out using technical grade solvents.

Chemicals. Fmoc-(L)-Arg(Pbf)-OH, Fmoc-(D)-Arg(Pbf)-OH, propargylamine, sodium azide and 4(dimethylamino)-pyridine (DMAP) were purchased from FLUOROCHEM and used without further purification. Boc-(L)-Arg(Pbf)-OH, Boc-(D)-Arg(Pbf)-OH were purchased from CARBOLUTION and used without further purification. Lithium hydroxide and diethylamine were purchased from ACROS and used without further purification. 1-Octyne and 4-methylmorpholine (NMM) were purchased from ALFA AESAR and used without further purification. O-(1H-6-Chlorobenzotriazole-1-yl)-1,1,3,3-tetramethyl-uronium hexafluorophos-phate (HCTU) was purchased from IRIS BIOTECH and used without further purification. $N, N$-Dicyclohexylcarbodiimide (DCC) was purchased from MERCK and used without further purification. Sulfury chloride was purchased from SIGMA ALDRICH and used without further purification. Imidazole was purchased from BASF and used without 
further purification. Potassium carbonate was purchased from RoTH and used without further purification. Copper sulphate pentahydrate was purchased from APPLICHEM and used without further purification. Monosodium ascorbate was purchased from $\mathrm{TCl}$ and used without further purification. Compound Fmoc-( $L$ )$\operatorname{Arg}(\mathrm{Pbf})-\mathrm{OMe}((L)-1)^{[23]}$ and Boc-(L)-Arg(Pbf)-OMe $((L)-8)^{[24]}$ were prepared according to a modified literature procedure. $N$-succinimide-GCP $(3)^{[25]}$ and the diazo transfer reagent imidazol-1-sulfonyl azide hydrogensulfate ${ }^{[19]}$ were synthesized according to literature procedures.

\section{Methyl(s)-2-azido-5-(3-((2,2,4,6,7-pentamethyl-2,3-dihydrobenzofuran-5-yl)sulfonyl)guanidino)-pentanoate} ((L)-2). Fmoc-(L)-Arg(Pbf)-OMe ((L)-1) (3.00 g, $4.53 \mathrm{mmol}, 1 \mathrm{eq})$ was dissolved in dimethylformamide (20 mL) and diethylamine $(9 \mathrm{~mL})$ was added. The solution was stirred for $2 \mathrm{~h}$ at RT. The crude mixture was concentrated in vacuo. The residue was dissolved in $\mathrm{MeOH}(20 \mathrm{~mL}) . \mathrm{K}_{2} \mathrm{CO}_{3}(1.81 \mathrm{~g}, 13.6 \mathrm{mmol}, 3 \mathrm{eq})$, imidazol1-sulfonyl azide hydrogensulfate $(1.84 \mathrm{~g}, 6.79 \mathrm{mmol}, 1.5 \mathrm{eq})$ and copper sulfate pentahydrate $(113 \mathrm{mg}, 453$ $\mu \mathrm{mol}, 0.1 \mathrm{eq})$ were added and the reaction mixture was stirred at RT overnight. The crude mixture was concentrated in vacuo and then dissolved in EtOAc $(50 \mathrm{~mL})$. The organic phase was washed with saturated $\mathrm{NaCl}$ solution $(3 \times 50 \mathrm{~mL})$ and $\mathrm{H}_{2} \mathrm{O}(3 \times 50 \mathrm{~mL})$. The organic phase was dried over $\mathrm{MgSO}_{4}$, filtered and concentrated in vacuo. The crude mixture was purified by silica gel column chromatography $(5.5 \mathrm{~cm} \times 18 \mathrm{~cm}$, $\mathrm{CH}_{2} \mathrm{Cl}_{2}$ :EtOAc $\left.=1: 2\right)$ to afford a $(L)-2$ as a clear, yellow oil $(1.46 \mathrm{~g}, 3.13 \mathrm{mmol}, 69.1 \%) .{ }^{1} \mathrm{H}-\mathrm{NMR}(600 \mathrm{MHz}$, DMSO-d $)[\mathrm{ppm}] \delta=6.71-6.45(\mathrm{~m}, 3 \mathrm{H}), 4.27(\mathrm{dd}, 3 \mathrm{~J} 5.1 \mathrm{~Hz}, 3 \mathrm{~J} 8.3 \mathrm{~Hz}, 1 \mathrm{H}), 3.70(\mathrm{~s}, 3 \mathrm{H}), 3.05(\mathrm{q}, 3 \mathrm{~J} 6.5 \mathrm{~Hz}, 2 \mathrm{H})$, $2.96(\mathrm{~s}, 2 \mathrm{H}), 2.48(\mathrm{~s}, 3 \mathrm{H}), 2.42(\mathrm{~s}, 3 \mathrm{H}), 2.01(\mathrm{~s}, 3 \mathrm{H}), 1.69-1.57(\mathrm{~m}, 2 \mathrm{H}), 1.45-1.36(\mathrm{~m}, 2 \mathrm{H}), 1.41(\mathrm{~s}, 6 \mathrm{H}) .{ }^{13} \mathrm{C}-$ NMR (151 MHz, DMSO-d $)$ [ppm] $\delta=170.6$ (1 C), 157.5 (1 C), 156.0 (1 C), 137.3 (1 C), $131.4(2 \mathrm{C}), 124.3$ (1 C), 116.3 (1 C), 86.3 (1 C), 60.9 (1 C), 52.5 (1 C), 42.5 (1 C), 39.3 (1 C), 28.0 (2 C), 28.3 (1 C), 25.3 (1 C), 19.0 (1 C), 17.6 (1 C), 12.3 (1 C). HR-ESI-pos (MeOH): $\mathrm{m} / z=467.2017$ (calcd 467.2071 for $\left.[\mathrm{M}+\mathrm{H}]^{+}\right), \mathrm{m} / z=489.1887$ (calcd 489.1891 for $\left.[\mathrm{M}+\mathrm{Na}]^{+}\right)$.

Methyl(s)-2-(4-((5-((N-(tert-butoxycarbonyl)carbamimidoyl)carbamoyl)-1H-pyrrole-2-carboxamido)methyl)1H-1,2,3-triazol-1-yl)-5-(3-((2,2,4,6,7-pentamethyl-2,3-dihydrobenzofuran-5-yl)sulfonyl)guanidino)-

pentanoate ((L)-4). Azido acid (L)-2 (400 mg, $1.20 \mathrm{mmol}, 1 \mathrm{eq})$ and GCP alkyne 3 (672 mg, $1.44 \mathrm{mmol}, 1.1 \mathrm{eq})$ were dissolved in THF $(20 \mathrm{~mL})$. A solution of copper sulfate pentahydrate $(30.0 \mathrm{mg}, 120 \mu \mathrm{mol}, 0.1 \mathrm{eq})$ and sodium ascorbate $(47.5 \mathrm{mg}, 240 \mu \mathrm{mol}, 0.2 \mathrm{eq})$ in degassed $\mathrm{H}_{2} \mathrm{O}(1 \mathrm{~mL})$ was freshly prepared. An aliquot of the fresh catalyst solution $(100 \mu \mathrm{L}, 12.0 \mu \mathrm{mol}, 0.01 \mathrm{eq})$ was added to the reaction solution and the reaction mixture was stirred at RT overnight. The crude mixture was concentrated in vacuo and then dissolved in EtOAc $(50 \mathrm{~mL})$. The organic phase was washed with saturated $\mathrm{NaCl}$ solution $(3 \times 50 \mathrm{~mL})$ and $\mathrm{H}_{2} \mathrm{O}(3 \times 50 \mathrm{~mL})$. The organic phase was dried over $\mathrm{MghSO}_{4}$, filtered and concentrated in vacuo. The crude mixture was purified by silica gel column chromatography $\left(4 \mathrm{~cm} \times 18 \mathrm{~cm}, \mathrm{CH}_{2} \mathrm{Cl}_{2}: \mathrm{MeOH}: \mathrm{NH}_{3}\left(25 \%\right.\right.$ in $\left.\left.\mathrm{H}_{2} \mathrm{O}\right)=9: 0.9: 0.1\right)$ to afford a $(L)-4$ as a white solid (860 mg, $1.08 \mathrm{mmol}, 89.6 \%) .{ }^{1} \mathrm{H}-\mathrm{NMR}\left(400 \mathrm{MHz}, \mathrm{DMSO}-d_{6}\right)$ [ppm] $\delta=11.10$ (br s, $1 \mathrm{H}$ ), 10.86 (br s, $1 \mathrm{H}), 9.33$ (br s, $1 \mathrm{H}), 8.90(\mathrm{t}, 3 \mathrm{~J} 5.6 \mathrm{~Hz}, 1 \mathrm{H}), 8.56$ (br s, $1 \mathrm{H}), 8.06(\mathrm{~s}, 1 \mathrm{H}), 6.81(\mathrm{~m}, 2 \mathrm{H}), 6.76-6.50(\mathrm{~m}, 3 \mathrm{H}), 5.51$

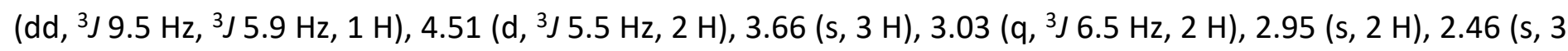
$\mathrm{H}), 2.40(\mathrm{~s}, 3 \mathrm{H}), 2.14(\mathrm{~m}, 2 \mathrm{H}), 2.00(\mathrm{~s}, 3 \mathrm{H}), 1.46(\mathrm{~s}, 9 \mathrm{H}), 1.40(\mathrm{~s}, 6 \mathrm{H}), 1.33-1.15(\mathrm{~m}, 2 \mathrm{H}) .{ }^{13} \mathrm{C}-\mathrm{NMR}(101 \mathrm{MHz}$, DMSO- $\left.d_{6}\right)[\mathrm{ppm}] \delta=169.1(2 \mathrm{C}), 159.5(2 \mathrm{C}), 157.5$ (1 C), 156.0 (2 C), $144.8(1 \mathrm{C}), 137.3(1 \mathrm{C}), 134.1$ (2 C), 131.4 (2 C), 124.3 (1 C), 123.1 (1 C), 116.3 (1 C), 112.1 (2 C), $86.3(1 \mathrm{C}), 61.3(1 \mathrm{C}), 52.7(1 \mathrm{C}), 42.5(2 \mathrm{C}), 39.3(1 \mathrm{C})$, 34.2 (1 C), 28.3 (4 C), 28.2 (2 C), 25.5 (1 C), 18.9 (1 C), 17.6 (1 C), 12.3 (1 C). HR-ESI-pos (MeOH): $\mathrm{m} / z=$ 800.3502 (calcd 800.3508 for $[\mathrm{M}+\mathrm{H}]^{+}$).

(s)-2-(4-((5-((N-(tert-Butoxycarbonyl)carbamimidoyl)carbamoyl)-1H-pyrrole-2-carboxamido)methyl)-1H1,2,3-triazol-1-yl)-5-(3-((2,2,4,6,7-pentamethyl-2,3-dihydrobenzofuran-5-yl)sulfonyl)guanidino)- $\mathrm{N}$-(prop-2yn-1-yl)-Pentanamide ((L)-5). Methyl ester (L)-4 (500 mg, $625 \mu \mathrm{mol}, 1$ eq) was dissolved in THF (20 mL). An 
aqueous solution of $\mathrm{LiOH}(45.1 \mathrm{mg}, 1.88 \mathrm{mmol}, 3 \mathrm{eq})$ in $\mathrm{H}_{2} \mathrm{O}(5 \mathrm{~mL})$ was added. The solution was stirred for 3 hours at RT. EtOAc $(50 \mathrm{~mL})$ was added to the solution and the aqueous phase was extracted repeatedly with EtOAc $(3 \times 50 \mathrm{~mL})$. The organic phase was dried over $\mathrm{MgSO}_{4}$, filtered and concentrated in vacuo. Evaporation of organic solvents gave the Me-deprotected compound as a white solid (491 mg), which could directly be used for the next step. The crude carboxylic acid (400 mg, $508 \mu \mathrm{mol}, 1 \mathrm{eq})$, propargylamine $(63.1 \mathrm{mg}, 1.15$ $\mathrm{mmol}, 2 \mathrm{eq})$ and 4-methyl-morpholine $(290 \mathrm{mg}, 2.86 \mathrm{mmol}, 5 \mathrm{eq})$ were dissolved in dry DMF (20 mL) under argon atmosphere. After stirring for 10 minutes at RT, HCTU (709 mg, $1.72 \mathrm{mmol}, 2 \mathrm{eq}$ ) was added the mixture was stirred overnight at RT. The crude mixture was concentrated in vacuo. The crude mixture was dissolved in EtOAc $(50 \mathrm{~mL})$ and the organic phase was washed with saturated $\mathrm{NaCl}$ solution $(3 \times 50 \mathrm{~mL})$ and $\mathrm{H}_{2} \mathrm{O}(3 \times 50$ $\mathrm{mL}$ ). The organic phase was dried over $\mathrm{MgSO}_{4}$, filtered and concentrated in vacuo. The crude mixture was

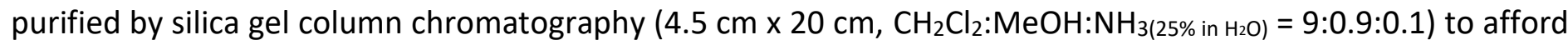
a (L)-5 as a white solid (309 mg, $375 \mu \mathrm{mol}, 67.5 \%) .{ }^{1} \mathrm{H}-\mathrm{NMR}\left(400 \mathrm{MHz}, \mathrm{DMSO}-d_{6}\right)$ [ppm] $\delta=11.15$ (br s, $1 \mathrm{H}$ ), 10.85 (br s, $1 \mathrm{H}), 9.33$ (br s, $1 \mathrm{H}), 8.94$ (t, $\left.{ }^{2} \mathrm{~J} 5.2 \mathrm{~Hz}, 1 \mathrm{H}\right), 8.86$ (t, $\left.{ }^{2} \mathrm{~J} 5.6 \mathrm{~Hz}, 1 \mathrm{H}\right), 8.56(\mathrm{br} \mathrm{s}, 1 \mathrm{H}), 8.03$ (s, $\left.1 \mathrm{H}\right)$, $6.82(\mathrm{~m}, 2 \mathrm{H}), 6.73-6.50(\mathrm{~m}, 3 \mathrm{H}), 5.25(\mathrm{t}, 3 \mathrm{~J} 7.4 \mathrm{~Hz}, 1 \mathrm{H}), 4.50$ (t, 3J $4.6 \mathrm{~Hz}, 2 \mathrm{H}), 3.89$ (dd, 3J 5.4 Hz, ${ }^{4} \mathrm{~J} 2.3 \mathrm{~Hz}, 2$ H), 3.15 (t, 光 $2.6 \mathrm{~Hz}, 1 \mathrm{H}$ ), 3.03 (q, ${ }^{2}$ J $\left.5.4 \mathrm{~Hz}, 2 \mathrm{H}\right), 2.95(\mathrm{~s}, 2 \mathrm{H}), 2.46(\mathrm{~s}, 3 \mathrm{H}), 2.40(\mathrm{~s}, 3 \mathrm{H}), 2.04-1.97(\mathrm{~m}, 2 \mathrm{H})$, $2.00(\mathrm{~s}, 3 \mathrm{H}), 1.46(\mathrm{~s}, 9 \mathrm{H}), 1.40(\mathrm{~s}, 6 \mathrm{H}), 1.30-1.23(\mathrm{~s}, 2 \mathrm{H}) .{ }^{13} \mathrm{C}-\mathrm{NMR}\left(101 \mathrm{MHz}, \mathrm{DMSO}-d_{6}\right)[p p m] \delta=167.5(2 \mathrm{C})$, 159.5 (2 C), 157.5 (1 C), 156.0 (2 C), 144.8 (1 C), 137.3 (1 C), 134.1 (2 C), 131.4 (2 C), 124.3 (1 C), 121.9 (1 C), 116.3 (1 C), 112.1 (2 C), 86.3 (1 C), 80.3 (1 C), 73.7 (1 C), 62.1 (1 C), 42.5 (2 C), 39.3 (1 C), 34.2 (1 C), 29.5 (1 C), 28.3 (3 C), 28.2 (1 C), 27.8 (1 C), 25.5 (1 C), 18.9 (1 C), 17.6 (1 C), 12.3 (1 C). HR-ESI-pos (MeOH): m/z = 823.3670 (calcd 823.3668 for $\left.[\mathrm{M}+\mathrm{H}]^{+}\right), 845.3486\left(\right.$ calcd 845.3487 for $\left.[\mathrm{M}+\mathrm{Na}]^{+}\right)$.

Methyl(s)-2-(4-hexyl-1H-1,2,3-triazol-1-yl)-5-(3-((2,2,4,6,7-pentamethyl-2,3-dihydrobenzofuran-5-

yl)sulfonyl)guanidino)pentanoate ((L)-6). Azido acid (L)-2 (300 mg, $429 \mu \mathrm{mol}, 1 \mathrm{eq})$ and 1-octyne (70.9 mg, 643 $\mu \mathrm{mol}, 1.5 \mathrm{eq})$ were dissolved in THF $(20 \mathrm{~mL})$. A solution of copper sulfate pentahydrate $(10.7 \mathrm{mg}, 42.9 \mu \mathrm{mol}$, $0.1 \mathrm{eq})$ and sodium ascorbate $(17.0 \mathrm{mg}, 85.8 \mu \mathrm{mol}, 0.2 \mathrm{eq})$ in degassed $\mathrm{H}_{2} \mathrm{O}(1 \mathrm{~mL})$ was freshly prepared. An aliquot of the fresh catalyst solution $(100 \mu \mathrm{L}, 4.29 \mu \mathrm{mol}, 0.01 \mathrm{eq})$ was added and the reaction was stirred at RT overnight. The crude mixture was concentrated in vacuo and then dissolved in EtOAc $(20 \mathrm{~mL})$. The organic phase was washed with saturated $\mathrm{NaCl}$ solution $(3 \times 50 \mathrm{~mL})$ and water $(3 \times 50 \mathrm{~mL})$. The organic phase was dried over $\mathrm{MgSO}_{4}$, filtered and concentrated in vacuo. The crude mixture was purified by silica gel column chromatography $\left(3.5 \mathrm{~cm} \times 18 \mathrm{~cm}, \mathrm{CH}_{2} \mathrm{Cl}_{2}\right.$ :EtOAc = 1:1) to afford a $(L)-6$ as a white solid (162 $\mathrm{mg}, 281 \mu \mathrm{mol}$, 65.5\%). ${ }^{1} \mathrm{H}-\mathrm{NMR}\left(600 \mathrm{MHz}, \mathrm{DMSO}-d_{6}\right)[\mathrm{ppm}] \delta=7.91(\mathrm{~s}, 1 \mathrm{H}), 6.69-6.40(\mathrm{~m}, 3 \mathrm{H}), 5.44\left(\mathrm{dd},{ }^{3} \mathrm{~J} 9.8 \mathrm{~Hz},{ }^{3} \mathrm{~J} 5.5 \mathrm{~Hz}, 1\right.$

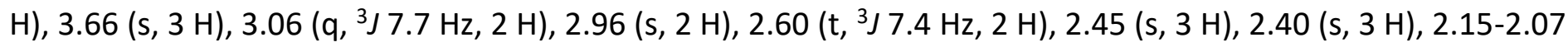
$(\mathrm{m}, 2 \mathrm{H}), 2.00(\mathrm{~s}, 3 \mathrm{H}), 1.61-1.54(\mathrm{~m}, 2 \mathrm{H}), 1.40(\mathrm{~s}, 6 \mathrm{H}), 1.27-1.11(\mathrm{~m}, 8 \mathrm{H}), 0.85\left(\mathrm{t},{ }^{3} \mathrm{~J} 6.9 \mathrm{~Hz}, 3 \mathrm{H}\right) .{ }^{13} \mathrm{C}-\mathrm{NMR}(101$ $\left.\mathrm{MHz}, \mathrm{DMSO}-d_{6}\right)[\mathrm{ppm}] \delta=169.2(1 \mathrm{C}), 157.5(1 \mathrm{C}), 156.0(1 \mathrm{C}), 147.0(1 \mathrm{C}), 137.3(1 \mathrm{C}), 131.4(2 \mathrm{C}), 124.3(1 \mathrm{C})$, 121.7 (1 C), 116.3 (1 C), 86.3 (1 C), 61.3 (1 C), 52.7 (1 C), 42.5 (1 C), 39.3 (1 C), 31.0 (1 C), 28.8 (1 C), 28.3 (2 C), 28.2 (1 C), 25.4 (2 C), 25.0 (1 C), 22.0 (1 C), 19.0 (1 C), 17.6 (1 C), 13.9 (1 C), 12.3 (1 C). HR-ESI-pos (MeOH): m/z $=577.3171\left(\right.$ calcd 577.3167 for $\left.[\mathrm{M}+\mathrm{H}]^{+}\right), m / z=599.2986\left(\right.$ calcd 599.2989 for $\left.[\mathrm{M}+\mathrm{Na}]^{+}\right)$.

\section{(s)-2-(4-Hexyl-1H-1,2,3-triazol-1-yl)-5-(3-((2,2,4,6,7-pentamethyl-2,3-dihydrobenzofuran-5-}

yl)sulfonyl)guanidino)-N-(prop-2-yn-1-yl)-Pentanamide ((L)-7). Methyl ester (L)-6 (75.0 mg, $130 \mu \mathrm{mol}, 1 \mathrm{eq})$ was dissolved in THF (20 mL). An aqueous solution of $\mathrm{LiOH}(9.34 \mathrm{mg}, 390 \mu \mathrm{mol}, 3 \mathrm{eq})$ in $\mathrm{H}_{2} \mathrm{O}(5 \mathrm{~mL})$ was added. The solution was stirred for 3 hours at RT. EtOAc $(50 \mathrm{~mL})$ was added to the solution and the aqueous phase was extracted repeatedly with EtOAc $(3 \times 50 \mathrm{~mL})$. The organic phase was dried over $\mathrm{MgSO}_{4}$, filtered and concentrated in vacuo. Evaporation of organic solvents gave the Me-deprotected compound as a white solid (74 mg), which could directly be used for the next step. The crude carboxylic acid (60.0 mg, $107 \mu \mathrm{mol}, 1 \mathrm{eq})$, propargylamine $(11.7 \mathrm{mg}, 213 \mu \mathrm{mol}, 2 \mathrm{eq}$ ) and 4-methylmorpholine (53.9 mg, $533 \mu \mathrm{mol}, 5 \mathrm{eq})$ were dissolved 
in dry DMF $(20 \mathrm{~mL})$ under argon atmosphere. After stirring 10 minutes at RT, HCTU (88.0 mg, $213 \mu \mathrm{mol}, 2 \mathrm{eq})$ was added and the solution and was stirred overnight at RT. The crude mixture was concentrated in vacuo. The crude mixture was dissolved in EtOAc $(50 \mathrm{~mL})$ and the organic phase was washed with saturated $\mathrm{NaCl}$ solution $(3 \times 20 \mathrm{~mL})$ and $\mathrm{H}_{2} \mathrm{O}(3 \times 20 \mathrm{~mL})$. The organic phase was dried over $\mathrm{MgSO}_{4}$, filtered and concentrated in vacuo. The crude mixture was purified by silica gel column chromatography $\left(5.5 \mathrm{~cm} \times 20 \mathrm{~cm}, \mathrm{CH}_{2} \mathrm{Cl}_{2}: \mathrm{EtOAc}=\right.$ $1: 2$ ) to afford a ( $L$ )-7 as a white solid (45.0 mg, $75.0 \mu \mathrm{mol}, 69.7 \%) .{ }^{1} \mathrm{H}-\mathrm{NMR}\left(600 \mathrm{MHz}, \mathrm{DMSO}-d_{6}\right)[\mathrm{ppm}] \delta=8.88$ (t, 3J $5.6 \mathrm{~Hz}, 1 \mathrm{H}), 7.87(\mathrm{~s}, 1 \mathrm{H}), 6.70-6.40(\mathrm{~m}, 3 \mathrm{H}), 5.20$ (t, ${ }^{2}$ J $\left.5.8 \mathrm{~Hz}, 1 \mathrm{H}\right), 3.88$ (dd, 3J $5.5 \mathrm{~Hz}, 4$ J $\left.2.6 \mathrm{~Hz}, 2 \mathrm{H}\right), 3.15$ (t, 光 $2.6 \mathrm{~Hz}, 1 \mathrm{H}$ ), 3.04 (q, ${ }^{3}$ J $\left.7.7 \mathrm{~Hz}, 2 \mathrm{H}\right), 2.96$ (s, $\left.2 \mathrm{H}\right), 2.59$ (t, 3 J $\left.7.8 \mathrm{~Hz}, 2 \mathrm{H}\right), 2.46(\mathrm{~s}, 3 \mathrm{H}), 2.40$ (s, $\left.3 \mathrm{H}\right), 2.00$ (s, $3 \mathrm{H}), 1.98(\mathrm{~m}, 2 \mathrm{H}), 1.59-1.56(\mathrm{~m}, 2 \mathrm{H}), 1.41(\mathrm{~s}, 6 \mathrm{H}), 1.27-1.18(\mathrm{~m}, 8 \mathrm{H}), 0.85\left(\mathrm{t},{ }^{2} \mathrm{~J} 7.4 \mathrm{~Hz}, 3 \mathrm{H}\right) .{ }^{13} \mathrm{C}-\mathrm{NMR}(101$ $\left.\mathrm{MHz}, \mathrm{DMSO}-d_{6}\right)[\mathrm{ppm}] \delta=167.7$ (1 C), 157.5 (1 C), 156.0 (1 C), 146.9 (1 C), 137.3 (1 C), 131.4 (2 C), 124.3 (1 C), 120.7 (1 C), 116.3 (1 C), 86.3 (1 C), 80.3 (1 C), 73.6 (1 C), 62.0 (1 C), 42.5 (1 C), 39.3 (1 C), 31.0 (1 C), 29.4 (1 C), 28.9 (2 C), 28.31 (1 C), 28.29 (2 C), 28.2 (1 C), 25.1 (1 C), 22.0 (1 C), 19.0 (1 C), 17.6 (1 C), 13.9 (1 C), 12.3 (1 C). HR-ESI-pos (MeOH): $m / z=600.3325$ (calcd 600.3327 for $[\mathrm{M}+\mathrm{H}]^{+}$), $m / z=622.3141$ (calcd 622.3146 for $\left.[\mathrm{M}+\mathrm{Na}]^{+}\right)$.

\section{tert-Butyl(s)-(1-oxo-5-(3-((2,2,4,6,7-pentamethyl-2,3-dihydrobenzofuran-5-yl)sulfonyl)guanidino)-1-(prop-2-} yn-1-ylamino)pentan-2-yl)carbamate ((L)-9). Boc-(L)-Arg(Pbf)-OMe ((L)-8) (100 mg, $185 \mu \mathrm{mol}, 1$ eq), was dissolved in THF (10 mL). An aqueous solution of $\mathrm{LiOH}(13.3 \mathrm{mg}, 555 \mu \mathrm{mol}, 3 \mathrm{eq})$ in $\mathrm{H}_{2} \mathrm{O}(2.5 \mathrm{~mL})$ was added. The solution was stirred for 3 hours at RT. EtOAc $(20 \mathrm{~mL})$ was added to the solution and the aqueous phase was extracted repeatedly with EtOAc $(3 \times 20 \mathrm{~mL})$. The organic phase was dried over $\mathrm{MgSO}_{4}$, filtered and concentrated in vacuo. Evaporation of organic solvents gave the Me-deprotected compound as a white solid (98 mg), which could directly be used for the next step. The crude carboxylic acid (98.0 mg, $186 \mu \mathrm{mol}, 1 \mathrm{eq}$ ), propargylamine $(20.5 \mathrm{mg}, 372 \mu \mathrm{mol}, 2 \mathrm{eq})$ and 4-methylmorpholine $(94.1 \mathrm{mg}, 930 \mu \mathrm{mol}, 5 \mathrm{eq})$ were dissolved in dry DMF (15 mL) under argon atmosphere. After stirring 10 minutes at RT, HCTU (115 mg, $297 \mu \mathrm{mol}, 1.5 \mathrm{eq})$ was added and the solution and was stirred overnight at RT. The crude mixture was concentrated in vacuo. The crude mixture was dissolved in EtOAc $(20 \mathrm{~mL})$ and the organic phase was washed with saturated $\mathrm{NaCl}$ solution $(3 \times 20 \mathrm{~mL})$ and $\mathrm{H}_{2} \mathrm{O}(3 \times 20 \mathrm{~mL})$. The organic phase was dried over $\mathrm{MgSO}_{4}$, filtered and concentrated in vacuo. The crude mixture was purified by silica gel column chromatography $\left(2.5 \mathrm{~cm} \times 10 \mathrm{~cm}, \mathrm{CH}_{2} \mathrm{Cl}_{2}\right.$ : $\mathrm{EtOAC}=$ $1: 4$ ) to afford a (L)-9 as a white solid (76.0 mg, $135 \mu \mathrm{mol}, 72.5 \%) .{ }^{1} \mathrm{H}-\mathrm{NMR}$ (600 MHz, DMSO- $\left.d_{6}\right)[\mathrm{ppm}] \delta=8.25$ (t, $1 \mathrm{H},{ }^{3}$ J $\left.5.4 \mathrm{~Hz}\right), 6.83\left(\mathrm{~d}, 1 \mathrm{H},{ }^{3} \mathrm{~J} 8.2 \mathrm{~Hz}\right), 6.66-6.37(\mathrm{~m}, 3 \mathrm{H}), 3.89-3.85(\mathrm{~m}, 1 \mathrm{H}), 3.84-3.83(\mathrm{~m}, 2 \mathrm{H}), 3.08(\mathrm{t}, 1 \mathrm{H}$, 3J $2.4 \mathrm{~Hz}$ ), 3.01 (q, $\left.{ }^{3} \mathrm{~J} 6.6 \mathrm{~Hz}, 2 \mathrm{H}\right), 2.96(\mathrm{~s}, 2 \mathrm{H}), 2.47(\mathrm{~s}, 3 \mathrm{H}), 2.42(\mathrm{~s}, 3 \mathrm{H}), 2.00(\mathrm{~s}, 3 \mathrm{H}), 1.57-1.34(\mathrm{~m}, 4 \mathrm{H}), 1.41$ $(\mathrm{s}, 6 \mathrm{H}), 1.37$ (s, $9 \mathrm{H}) .{ }^{13} \mathrm{C}-\mathrm{NMR}\left(101 \mathrm{MHz}, \mathrm{DMSO}-d_{6}\right)$ [ppm] $\delta=171.8(1 \mathrm{C}), 157.4(1 \mathrm{C}), 156.0$ (1 C), 155.3 (1 C), 137.3 (1 C), 131.4 (2 C), 124.3 (1 C), 116.3 (1 C), 86.3 (1 C), 81.0 (1 C), 78.0 (2 C), 73.0 (1 C), 53.8 (1 C), 42.5 (1 C), 39.3 (1 C), 28.3 (3 C), 28.2 (1 C), 27.9 (2 C), 25.6 (1 C), 19.0 (1 C), 17.6 (1 C), 12.3 (1 C). HR-ESI-pos (MeOH): $m / z=564.2849\left(\right.$ calcd 564.2850 for $\left.[\mathrm{M}+\mathrm{H}]^{+}\right), m / z=586.2666\left(\right.$ calcd 586.2670 for $\left.[\mathrm{M}+\mathrm{Na}]^{+}\right)$.

\section{Acknowledgements}

We gratefully acknowledge funding by the DFG (Heisenberg-fellowship for J.N., NI1273/4-1). Special thanks go to Prof. Benjamin List and Stefanie Dehn from the MPI Mülheim for performing the chiral HPLC analysis of compound (L)-5. 


\section{Supplementary Material}

The supplementary material file can be found in the online version. It contains all synthetic procedures and analytical data, including ${ }^{1} \mathrm{H}$ and ${ }^{13} \mathrm{C}$ NMR spectra and HPLC traces.

\section{References}

1. Nelson D. L.; Cox M. M., Principles of Biochemistry, W. H. Freeman, New York, 2005.

2. Valeur, E.; Bradley, M. Chem. Soc. Rev. 2009, 38, 606-631. https://doi.org/10.1039/B701677H

3. Giese, M.; Niemeyer, J.; Voskuhl, J. ChemPlusChem. 2020, 5, 985-997. https://doi.org/10.1002/cplu.202000142

4. Schmuck, C. Chem. Commun. 1999, 843-844. https://doi.org/10.1039/A901126I

5. Li, M.; Schlesiger, S.; Knauer, S. K.; Schmuck, C. Org. Biomol. Chem. 2016, 14, 8800-8803. https://doi.org/10.1039/C6OB01584K

6. Maity, C.; Schmuck, C. Chem. Eur. J. 2016, 22, 13156-13161. https://doi.org/10.1002/chem.201602240

7. Hisamatsu, Y.; Banerjee, S.; Avinash, M. B.; Govindaraju, T.; Schmuck, C. Angew. Chem. Int. Ed. 2013, 52, $12550-12554$.

https://doi.org/10.1002/ange.201306986

8. Avinash, M. B.; Verheggen, E.; Schmuck, C.; Govindaraju, T. Angew. Chem. Int. Ed. 2021, 51, 10324-10328. https://doi.org/10.1002/anie.201204608

9. Grossert, G.; Sicking, W.; Zellermann, E.; Schmuck, C. Supra. Chem. 2018, 30, 395-403. https://doi.org/10.1080/10610278.2017.1392020

10. Samanta, K.; Jana, P.; Backer, S.; Knauer, S.; Schmuck, C. Chem. Commun. 2016, 52, 12446-12449. https://doi.org/10.1039/C6CC06404C

11. Jana, P.; Samanta, E.; Schmuck, C.; Backer, S.; Knauer, S. K. Angew. Chem. Int. Ed. 2017, 28, 8195-8200. https://doi.org/10.1002/ange.201700713

12. Junghänel, S.; Karcewski, S.; Bäcker, S.; Knauer, S. K.; Schmuck, C. ChemBioChem. 2017, 18, 2268-2279. https://doi.org/10.1002/cbic.201700433

13. Zaloom, J.; Roberts, D. C. J. Org. Chem. 1981, 46, 5173-5176. https://doi.org/10.1021/jo00338a022

14. Tron, G. C.; Pirali, T.; Billington, R. A.; Canonico, P. L.; Sorba, G. Genazzani A. A. Med. Res. Rev. 2008, 28, 278-308. https://doi.org/10.1002/med.20107

15. Tornøe, C. W.; Christensen, C.; Meldal, M. J. Org. Chem. 2002, 67, 3057-3064. https://doi.org/10.1021/jo011148j

16. Castro, V.; Rodriguez, H.; Albertico, F. ACS Comb. Sci. 2016, 18, 1, 1-14. https://doi.org/10.1021/acscombsci.5b00087

17. Ke, Z.; Chow, H-F.; Chan, M-C.; Liu, Z.; Sze, K-H. Org. Lett. 2012, 14, 1, 394-397. https://doi.org/10.1021/ol2031685

18. Wei, B.; Gunzner-Toste, J.; Yoa, H.; Safina, B. J. Med. Chem. 2018, 61, 989-1000. 
https://doi.org/10.1021/acs.jmedchem.7b01430

19. Potter, G. T.; Jayson, G. C.; Miller, G. J.; Gardiner, J. M. J. Org. Chem. 2016, 81, 8, 3443-3446. https://doi.org/10.1021/acs.joc.6b00177

20. Katritzky, A. R.; El Khatib, M.; Bol'shakov, O.; Khelashvili, L.; Steel, P. J. J. Org. Chem. 2010, 75, 19, 65326539.

https://doi.org/10.1021/jo101296s

21. Lundquist, J. T.; Pelletier, C. J. Org. Lett. 2001, 3, 5, 781-783. https://doi.org/10.1021/ol0155485

22. Katritzky, A. R.; Wang, Z.; Ji, Y.; Fang, Y. Arkivoc 2002 (iii), 46-54. https://doi.org/10.3998/ark.5550190.0003.304

23. Grogg, M.; Hilvert, D.; Albert, K.; Dieter, D. Synthesis 2019, 1, 31-39. https://doi.org/10.1055/s-0037-1610202

24. Ward, D. J.; Van de Langemheen, H.; Koehne, E.; Kreidenweiss, A.; Liskamp, R. M. J. Bioorg. Med. Chem. 2019, 13, 2857-2870. https://doi.org/10.1016/j.bmc.2019.05.014

25. Maity, D.; Li, M.; Ehlers, M.; Schmuck, C. Chem. Commun. 2017, 53, 208-211. https://doi.org/10.1039/C6CC08386B 